\title{
No princípio era o Rap: a construção do mito em Racionais MC'S
}

\author{
Bruno de Carvalho Rocha
}

Universidade Metodista de São Paulo - UMESP

Marcio Cappelli Aló Lopes

Universidade Metodista de São Paulo - UMESP

\section{Resumo}

Neste artigo abordaremos alguns aspectos referentes ao desenvolvimento do mito em Sobrevivendo no inferno, dos Racionais MC's. Primeiramente, procuraremos discernir a trajetória do mito no rap brasileiro a partir de três blocos históricos: (1) até os anos 1989, (2) 1990-1999 e (3) de 2000 em diante. A partir da concepção do rap enquanto literatura oral urbana, tentaremos esclarecer a relação do mito e da experiência religiosa com a obra em questão. Em seguida, buscaremos descrever como se dá a construção de uma cosmogonia periférica através da faixa Gênesis, e apresentaremos uma proposta de leitura metafórica do mito em alguns trechos da faixa Capitulo 4 versículo 3, a fim de encontrar um caminho de acesso ao conteúdo poético do texto.

Palavras-chave: Rap nacional; Racionais Mc's; Sobrevivendo no inferno; mito; metáfora.

\section{In the Beginning There Was Rap: Myth Construction in Racionais MC's $^{\prime}$}

\begin{abstract}
This article addresses some aspects related to the development of the myth in Sobrevivendo no Inferno, by Racionais Mc's. First, we will try to discern the trajectory of the myth in Brazilian rap from three historical blocks: (1) until 1989, (2) 1990-1999 and (3) from 2000 onwards. Based on the concept of rap as an urban oral literature, we will clarify myth and religious experience relation to the subject. Then, we will describe how the construction of a peripheral cosmogony occurs through the Genesis track, and propose a metaphorical reading of the myth in some parts of the track Chapter 4 verse 3 in order to find a path to the text poetic content.
\end{abstract}

Keywords: national Rap; Racionais MC's; Surviving in Hell; myth; metaphor. 


\section{En el principio era el Rap: la construcción del mito en Racionais MC's}

\section{Resumen}

En este artículo abordaremos algunos aspectos relacionados con el desarrollo del mito en Sobrevivendo no Inferno, de Racionais Mc's. Primero, buscaremos discernir la trayectoria del mito en el rap brasileño a partir de tres momentos históricos: (1) hasta 1989, (2) 1990-1999 y (3) a partir del 2000 en adelante. Partiendo del concepto del rap como literatura oral urbana, intentaremos aclarar la relación entre mito y experiencia religiosa con la obra en cuestión. Luego, intentaremos describir cómo se da la construcción de una cosmogonía periférica a través de la pista Génesis, y presentaremos una propuesta de lectura metafórica del mito en algunas partes de la canción Capitulo 4 versiculo 3, con el fin de encontrar una ruta de acceso. al contenido poético del texto.

Palabras clave: rap nacional; Racionais MC's; mito; metáfora.

\section{Introdução}

A relação entre mito ${ }^{1}$ e arte, principalmente na música e na literatura, já passou por inúmeras fases e formas. O crítico russo Eleazar M. Mielietinski, em seu livro A poética do mito (1987), afirma que muitos autores da literatura têm redescoberto o potencial "mitopoético" do texto, isto é, tem combinado elementos da mitologia com o objeto literário, desenvolvendo arquétipos narrativos por meio de modelos míticos. Já o crítico canadense Northrop Frye diz, por exemplo, que o princípio genético da poesia é o mito (2000, p.28), e que "os princípios estruturais da literatura relacionam-se (...) estreitamente com a mitologia e a religião" (FRYE, 1957, p. 136).

Não obstante o longo processo de emancipação da arte em relação à religião, que produziu uma irredutível afirmação da autonomia das duas esferas, é possível afirmar que o processo de remitologização experimentado no âmbito da sociedade contemporânea abre possibilidades para a utilização de um imaginário simbólico religioso. Imagens e narrativas míticas herdadas nos ajudam a repensar diversos aspectos da condição humana, sendo a literatura indispensável para esse exercício. Ou seja, numa tensão criativa, "a literatura atualiza os mitos quer no plano geral quer em relação à poética, exprimindo 'ideias eternas', cosmogonias e escatologias, origens do homem, realidades inefáveis e tantos outros conteúdos" (RIBEIRO, 2008, p. 61).

\footnotetext{
A compreensão do mito a qual recorremos inscreve-se na acepção de Mircea Eliade: "O mito conta uma história sagrada; ele relata um acontecimento ocorrido no tempo primordial, o tempo fabuloso do princípio. Em outros termos, o mito narra como, graças às façanhas dos Entes Sobrenaturais, uma realidade passou a existir, seja uma realidade total, o Cosmos, ou apenas um fragmento: uma ilha, uma espécie vegetal, um comportamento, uma instituição" (ELIADE, 1978, p. 11).
} 
Evidentemente, não só a literatura clássica ocidental e as diversas expressões das culturas orientais (orais, pictóricas e iconográficas) carregam questões sobre as origens e os deuses, mas autores como Dostoiévski, Tolstói ou José Saramago, estão repletos de reflexões teológicas, políticas e filosóficas sobre a religião. Em solo sul-americano, as novas configurações políticoculturais, étnicas e simbólicas dão contornos específicos à construção/ compreensão do sagrado. No Brasil, além dos clássicos de José de Alencar, Euclides da Cunha e Machado de Assis - inscritos numa estética literária, um tempo histórico e político, e religioso determinado - também surge, em um contexto mais recente, um novo tipo de dicção popular cuja representação podemos antever em Carolina Maria de Jesus. Tal dicção, chamada posteriormente de literatura marginal, foi se construindo historicamente entre causos, contos e canções.

A literatura marginal ou literatura periférica, portanto, é produto ou efeito colateral de diversos fatores culturais, geográficos e econômicos. O escritor Ferréz, autointitulado como "Datilógrafo do gueto", afirma que ela é uma narrativa cultural "da periferia feita por gente da periferia e ponto final" 3 . Isto é, carrega em sua estética uma "poética da sobrevivência" capaz de romper o silêncio do sujeito marginalizado frente à opressão vivida, dando protagonismo político de suas próprias histórias e ficções (ROCHA, 2007, p. 56).

A literatura marginal, como produto do imaginário periférico dos grandes centros urbanos, também se utiliza dos arquétipos mitológicos e religiosos locais. A narrativa de Paulo Lins, em Cidade de Deus, ou de Ferréz, em Capão Pecado, se encontram constantemente com símbolos, imagens e metáforas mitopoéticas capazes de abordar diversas questões humanas, sejam sociais ou religiosas, assim como o relato de Jocenir, em Diário de um detento, o livro - texto que descreve sua passagem pelo presídio Carandiru, em São Paulo, e como sobreviveu ao massacre ocorrido no ano de 1992.

Este último exemplo se torna importante para pensarmos o vínculo entre esse tipo de literatura e o rap. Mano Brown, integrante do grupo de rap Racionais MC's, lançou em 1997 a música Diário de um detento, produzida em parceria com o próprio Jocenir e já ali deixava evidente a importância da religião: "Vários tentaram fugir, eu também quero/ Mas de um a cem, a minha chance é zero/ Será que Deus ouviu minha oração?/ Será que o juiz aceitou a

2 Racionais Mc's, “Capítulo 4, versículo 3”, Lp Sobrevivendo no inferno. (São Paulo, Cosa Nostra Fonográfica, 1997).

3 Ferréz. "Contestação”. Caros amigos. Literatura marginal. Abril, 2004, p. 2. 


\section{Bruno de Carvalho Rocha}

Marcio Cappelli Aló Lopes

apelação?" . Não só pela relação entre Jocenir e Mano Brown, ou mesmo do escritor Ferréz com o rap ${ }^{5}$, é possível perceber uma relação intrínseca entre a literatura marginal e a música produzida na periferia. A literatura marginal reconhece que a leitura não está ao alcance de todos em seu contexto ${ }^{6}$, e o rap, enquanto literatura oral urbana ${ }^{7}$, ocupa uma função de "transmissão oral da cultura” (ROCHA, 2007, p. 42). A “escrita da voz" (BÉTHUNE, 2003, p. 52) no rap ganha contornos de um "novo realismo" (SALGADO, 2015, p. 154) literário e mágico, onde a narrativa mitológica aparece naturalmente na relação entre os motivos crítico-sociais e os da tradição folclórico-mitológica local (MONFARDINI, 2005, p. 57). Ou seja, o rap como uma literatura oral urbana e periférica compreende um conjunto de técnicas narrativas constantemente atravessadas por arquétipos mítico-religiosos próprios da cultura brasileira. O rapper Criolo, por exemplo, perguntado sobre o seu processo de criação, diz: "As coisas meio que aparecem na minha cabeça como um grande desafio. Toda vez que alguma inspiração vem, parece que é o divino brincando pra saber se eu tô vivo ou não e, a partir daí, eu tento decodificar com as minhas palavras" (CRIOLO, 2011).

Racionais MC's, considerado por muitos como o maior grupo de rap brasileiro, se soma à produção cultural e literária responsável pela formação do sujeito periférico (D’ANDREA, 2014) e sua "dialética da marginalidade" . Por meio de uma voz crítica e coletiva, o rap desenvolve uma narrativa ficcional de sua realidade, disputando o imaginário social e suas representações raciais, econômicas e religiosas. Racionais MC's, imerso dentro de um imaginário mítico-popular, narra uma experiência social

4 Racionais Mc's, "Diário de um detento", Lp Sobrevivendo no inferno. (São Paulo, Cosa Nostra Fonográfica, 1997)

5 Fora diversas participações com outros rappers, Ferréz lançou em 2003 um único álbum de rap chamado Determinação.

6 Na dedicatória do seu livro Capão Pecado, Ferréz escreve: "Este livro é dedicado também a todas as pessoas que não tiveram sequer uma chance real de ter uma vida digna; que não puderam ser cidadãos, pois lhe impediram de ter direitos, mas lhe foram cobrados deveres. (...) àqueles que não foram alfabetizados e, portanto, não poderão ler esta obra" (FERRÉZ, 2000).

7 "No código genético, o rap traz um regime estético em que se entrelaçam som e palavra. Esse regime insere-se plenamente numa tradição cultural de matriz africana na qual se verifica a sobrevivência das formas orais de literatura" (SALGADO, 2015, p. 151).

8 João Cezar de Castro Rocha afirma que a dialética da marginalidade se materializa em uma realidade social injusta de inúmeros impasses éticos em que alguns atores expressam uma voz popular coletiva que desvela as faces da violência e do racismo cotidiano, em oposição a uma "promessa incerta" de "reconciliação social" (ROCHA, 2007, p.162) 
atravessada por uma "teologia da sobrevivência" (OLIVEIRA, 2018, p. 32). Por meio de arquétipos e metáforas míticas, o grupo de rap consegue ser local, universal e atual, "como um relicário de vivências imaginárias aptas a forjar a metaforicidade literária sempre nova e, ao mesmo tempo, tão antiga" (RIBEIRO, 2008, p. 62).

Assim, para esboçar com mais acuidade a relação entre o mito e o rap dos Racionais, este artigo será desenvolvido em três momentos distintos: (1) a apresentação de um panorama geral da presença de mitos, imagens e metáforas religiosas em diversas produções do rap nacional. Em três blocos históricos diferentes (até os anos de 1989, de 1990 aos anos 1999, e de 2000 até as produções mais recentes), destacaremos alguns nomes importantes para a história do rap brasileiro e como o mito aparece em alguns trechos de sua literatura; (2) analisaremos também a construção do mito e da experiência religiosa dentro da obra Sobrevivendo no inferno; para em seguida (3) demonstrar o desenvolvimento de uma cosmogonia periférica presente na faixa Gênesis, e o destaque de algumas metáforas da faixa Capitulo 4, versículo 3, do mesmo álbum, e como elas podem ser um caminho de compreensão do mito na obra dos Racionais MC's.

\section{A história do mito no rap nacional}

O surgimento do rap no Brasil é algo fluido e complexo (OLIVEIRA, 2015, p. 41). Complexo por atravessar e provocar inúmeras transformações sociais e culturais no país. Ao mesmo tempo, é uma resposta natural de uma juventude ligada às equipes de baile dos anos 1970/1980, que, a partir de um movimento de identificação com a cultura periférica norte-americana, se expressa em meio a conflitos sociais urbanos e políticos, próprios de um Brasil marcado por resquícios ditatoriais e recém-democratizado. O rap nacional é expressão poético-política de uma população marginalizada que, em meio a condições de desamparo pelo Estado e marginalização por meio de uma política econômica neoliberal, se organiza e se reafirma enquanto sujeito coletivo que narra e escreve sobre sua própria história, identidade e seu lugar no mundo: "No código genético, o rap traz um regime estético em

\footnotetext{
9 Segundo o depoimento de Edi Rock no documentário “Racionais Mc’s: Uma história musical: "O baile black ele é uma enciclopédia, uma discopédia. Quando a gente começou a fazer rap, eu queria reproduzir aquilo que tocava no baile". O rapper Emicida segue dizendo que: "Musicalmente falando o Racionais sempre me trouxe uma sensação profunda de continuidade. É a exata continuação da cena de baile black de São Paulo, que é a geração dos nossos pais" (TIDAL, 2019).
} 
que se entrelaçam som e palavra. Esse regime insere-se plenamente numa tradição cultural de matriz africana na qual se verifica a sobrevivência das formas orais de literatura" (SALGADO, 2015, p. 151).

A literatura oral africana em diálogo com manifestações culturais da periferia de Nova Iorque, espalha-se em diversos continentes, inclusive no Brasil. Sendo próprio do ser-humano um esforço de compreender o mundo e suas origens (JOSGRILBER, 2014, p.29), a literatura se torna o lugar de construção simbólica e religiosa de uma experiência de sentido. Dentro de um cenário cultural híbrido, onde os povos em diáspora sobrevivem e se reinventam dentro de "espaços clandestinos", o rap acaba sendo fruto de "um legado de africanismos e um estoque de experiências religiosas" (GILROY, 2001, p.175) advindas do processo de escravidão racial tanto nos Estados Unidos como no Brasil. Tais experiências religiosas e narrativas mitológicas se constituem como resistência dentro de um processo colonial de apagamento sistemático de memórias fundantes dos povos escravizados. Estas, sobrevivem através da literatura oral (rap) e escrita da diáspora, por meio da narrativa de mitos que conservam identidade, história e sentido.

No Brasil, o rap é marcado tanto pelo processo político recente de redemocratização, organização social e ocupação dos espaços públicos pela juventude urbana (SOUZA, 2011, p. 66), como pela história colonial e seus desdobramentos, atingindo diretamente a formação do povo, sua condição histórica e existencial; críticas sociais e experiências religiosas. Assim, constata-se que o rap nacional é um fenômeno músico-literário atravessado por uma estrutura narrativa arquetípica em que os mitos são articulados com o objetivo de apreender, explicar e recontar a condição do sujeito periférico. A religião acaba sendo um elemento intrínseco à formação do povo brasileiro. E o cristianismo e as religiões afro-brasileiras (sem esquecer as expressões religiosas indígenas) estão efetivamente presentes no imaginário sincrético e popular do país, inclusive do rapper. O MC articula, em sua literatura oral urbana, mitos e imagens simbólicas disponíveis de seu contexto social, visando a localização temporal de sua comunidade, a preservação de sua memória e a construção de sentido e realidade.

Para compreender o desenvolvimento do mito no rap nacional, é importante visualizar três momentos históricos do gênero e destacar alguns grupos e nomes. O primeiro bloco histórico compreende o final dos anos 1980, os primeiros anos do rap no Brasil. Nestes anos iniciais, dois discos foram essenciais para construir a base do que viria a ser o rap nacional: Hiphop cultura de rua (1988) e Consciência Black Vol. 1 (1989). A primeira coletânea 
(1988) reuniu nomes como Thaíde e Dj Hum, Mc Jack, Código 13 e O credo. De maneira simbólica e propositiva, Thaide e Dj Hum abrem o disco com a música Corpo fechado. A música não só apresenta Thaíde ao seu público - "Meu nome é thaíde e não tenho r.g./ Não tenho c.i.c., perdi a profissional/ Nasci numa favela de parto natural/ Numa sexta feira santa que chovia pra valer" - mas carrega um pedido de proteção para o rap nacional: "Os demônios me protegem e os deuses também/ Ogum, iemanjá e outros santos ao além”. Thaíde apresenta uma realidade urbana com temas que ao longo dos anos preenchem o imaginário literário do rap: mitos e metáforas religiosas, contexto escolar da periferia, a polícia sempre presente na comunidade, o cárcere e a dimensão racial sempre evidente nesse cenário: "Não nasci loirinho com o olho verdinho/ Sou caboclinho comum nada bonitinho/ Feio e esperto com cara de mal/ Mas graças a Deus totalmente normal". Corpo fechado é um relato testemunhal de uma identidade periférica que precisa sobreviver em meio às tensões sociais adversas. Onde o Estado é ausente e falho, o mito e a experiência religiosa são críticas e atuantes, se somando às ferramentas disponíveis para a denúncia das desigualdades: "A minha lei sempre foi a lei do cão/ Não me arrependo de nada que eu fiz/ Saber que eu vou pro céu não me deixa feliz/ Essa prece que tu rezas eu já muito rezei/ E pro deus que tu confessas eu já muito me expliquei”.

A coletânea também conta com outros exemplos do imaginário mítico sempre presente no rap, como a música $O$ credo: "Tenho em minhas mãos um manifesto/Que me salva de afundar em um mundo que eu detesto/Nisso tudo eu piso e não tropeço/Meu manifesto é a força do Criador”. Além da ideia de que o rap é um tipo de manifesto, um documento curto que reivindica e se coloca ao lado de uma causa, existe a metáfora do "credo": um tipo de oração religiosa que confessa determinada doutrina. Há uma ideia de que, assim como a Bíblia é o credo ou o manifesto da religião institucionalizada, o rap é uma espécie de manifestação dotada simbolicamente de uma autoridade sagrada, sendo um instrumento que também "salva" do tropeço e que subsiste a partir da "força do Criador". Consciência Black Vol. I (1989), segundo disco deste bloco, além de conter os primeiros registros do grupo Racionais MC's, demonstra que as imagens mítico-religiosas também fazem parte de sua construção ficcional: "O fim está próximo, essa é minha versão/ Redimir-se todos, esta é a vocação/ Disse Jesus Cristo que na terra ia voltar/Vocês vão rezar, pro céu também olhar" ${ }^{\prime 10}$.

10 Street Dance, “Absoluto”, Lp Consiciência Black Vol. I (São Paulo, Zimbabwe Records, 1989). 
O segundo bloco histórico vai de 1990 até os anos 1999. Em meio à crescente política neoliberal que acentua as desigualdades sociais no país (LEITE, 2018, p. 160), essa década marca a consolidação do rap em território nacional e sua expansão nas periferias do Brasil. Nomes como RZO, Potencial 3, Facção Central, Realidade Cruel, Ndee Naldinho, Consciência Humana, Sistema Negro, Face da Morte, Happin Hood, Di Nadi, Racionais MC's, em São Paulo; Mv Bill, Planet Hemp, Gabriel Pensador, no Rio de Janeiro; Gog, Câmbio Negro, Viela 17, em Brasília; Faces do Subúrbio, Nação Zumbi e Mundo Livre S/A, no nordeste; foram responsáveis pela popularização e produção da cultura Hip-hop brasileira nos anos de 1990. A partir das múltiplas características regionais, o rap é incorporado à música popular do país, explorando ritmos, sonoridades e histórias de cada contexto sem perder sua identidade africana. Os já conhecidos Thaide e Dj Hum, no álbum Hip-bop na veia (1990) afirmam: "Na África existe uma irradiante luz negra/ Que faz com que todos nós negros tenhamos certeza/ Que um dia, dia-adia, seremos todos iguais/ Isso não se apagará jamais". Este álbum é uma reafirmação do movimento hip-hop e os elementos que o compõe. É uma demonstração de enfrentamento ao racismo, da formulação de uma crítica social consciente e um chamado à esperança: "A morte, ela não nos persegue/ Ela é negra como nós/ Você pensa que vai nos derrotar/ Mas não vai ser tão fácil como você pensa/ Pois você só tem suas ideias desabençoadas e nós temos a nossa crença".

O grupo de São Paulo Facção Central, se destaca neste período por um tipo de testemunho cruel e realista, capaz de chocar e escandalizar o ouvinte despreparado ${ }^{11}$. Observa-se que no início dos anos 1990, os rappers paulistanos são influenciados pela segunda geração do rap norte-americano que tinha como pauta principal a luta pelos direitos civis, a partir um discurso político agressivo contra o racismo e desigualdades sociais, baseados, principalmente, em figuras como Malcom X e Martin Luther King (SILVA,

11 O grupo Facção Central sofreu uma série de censuras e retaliações nos anos 2000, ao clipe e a música "Isto é uma guerra". O vídeo foi apreendido pelo Grupo de Atuação Especial e Repressão Contra o Crime Organizado, por apologia à violência, drogas e ao crime. Em resposta, Eduardo, ex-integrante do grupo, respondeu em gravação ao vivo: "Mano, se é apologia ao crime falar que as crianças passa fome, que muitos de nós não tem sequer dez centavos pra comprar um pão, que muitos de nós tão morrendo fumando crack, que muitos de nós tão morrendo trocando tiro com a polícia, então, que se foda: Facção vai fazer apologia ao crime". Facção Central, "Introdução", CD Ao vivo (São Paulo, Sky Blue, 2005). 
1999, p. 29). Facção Central, "direto do campo de extermínio", encarna a voz do "favelado" sem "freio na língua, sem meias-verdade, história engraçada e frase bonita. Facção Central, Chico Xavier do gueto, pondo no papel o que Deus manda" ${ }^{\prime 2}$. Em meio às metáforas religiosas e personagens míticos, Facção Central constrói uma escatologia periférica, descrevendo sua realidade social como "inferno" e o Estado, a fome e a violência enquanto responsáveis pela criação de "demônios":

O moleque tava ali, ninguém olhou até escorrer o sangue/ Criaram um demônio e esse é seu inferno, essa é sua história/ A história de um traficante ${ }^{13}$. Seja bem vindo a um lugar que Deus esqueceu/ Seja bem vindo a um capítulo da história que o demônio escreveu/ Os personagens aqui não são heróis não/ Na nossa história estão no cemitério ou na detenção ${ }^{14}$.

Estamos de luto aos manos que se foram/ Aê aos que ficaram meus pêsames, aguardem sua vez/ Não tem apelo pro inferno, nem oração lá pra cima/ Todo mundo já era é uma contagem regressiva ${ }^{15}$.

Racionais Mc's, um dos maiores grupos de rap do Brasil, se consolida nesta década com os álbuns Holocausto urbano (1990), Escolba seu caminho (1992), Raio-X do Brasil (1993) e Sobrevivendo no inferno (1997). Os dois primeiros trabalhos são resultado de um período de grande influência do movimento negro, de pautas anti-racistas e políticas: "Os anos 90 veio a consciência política, como preto, como brasileiro, veio o Racionais"16. Edi Rock segue dizendo que "92" foi a época "mais politizada, né, uma época 'conscientização', digamos assim. A fase que a gente falava da onde você veio, pra onde você vai, quem você é, o que você quer" ${ }^{17}$. O álbum Sobrevivendo no inferno, como sublinha Acuam Silvério Oliveira, foi a transição da "figura do professor autoritário dos primeiros discos cede[ndo] lugar à postura do pastor-marginal" (OLIVEIRA, 2018, p. 31). As imagens, os símbolos e a linguagem do disco de 1997 dialogam com o imaginário religioso da periferia

\footnotetext{
12 Facção Central, "Chico Xavier do gueto", Cd Direto do campo de extermínio (São Paulo, Face da morte produções, 2003).

13 Facção Central, "A história de um traficante", Cd Estamos de luto (São Paulo, Five Especial, 1998)

14 Facção Central, "Um lugar em decomposição", Cd Estamos de luto (São Paulo, Five Especial, 1998)

15 Facção Central, "Estamos de luto", Cd Estamos de luto (São Paulo, Five Especial, 1998)

16 Depoimento de Kl Jay, integrante dos Racionais Mc's no documentário Racionais 3 décadas. (TIDAL, 2019)

17 Depoimento de Edi Rock no documentário Racionais 3 décadas. (TIDAL, 2019)
} 


\section{Bruno de Carvalho Rocha}

Marcio Cappelli Aló Lopes

brasileira. Começando por uma capa que alude simbolicamente à Bíblia, tendo todo o desenvolvimento do disco estruturado no arquétipo religioso do texto bíblico, passando por músicas como Gênesis, Capitulo 4 versiculo 3, Diário de um detento, Fórmula mágica da paz, entre outras.

O último bloco histórico do rap adentra os anos 2000. O Brasil, neste período, experimenta uma ampliação significativa do significado de cultura. Através do governo Lula, principalmente por meio do secretário da cultura, Gilberto Gil, se amplia e reconhece-se cada vez mais manifestações regionais ligadas às tradições afro-brasileiras e sua diversidade religiosa, política e cultural $^{18}$. Além do rap nacional, o cinema brasileiro introduziu na cultura de massa histórias, tramas e o cotidiano periférico do país. Filmes como Cidade de Deus (2002), uma adaptação da literatura marginal de Paulo Lins, ou, Carandiru (2003), em que o rapper Sabotage participou como um dos atores, passaram a ser o contato entre as classes médias e altas com a realidade periférica brasileira. Trilha Sonora do Gueto, SNJ, Marcelo D2 e o próprio Sabotage, abrem um novo milênio com novas produções, pautas, avanços culturais no país, mas sem deixar de lado aspectos religiosos característicos à literatura oral urbana nacional: "Onilê, o Pai Ogum, Ai ei eô, Mãe Oxum/ Filho de Zambi, cansado de ver sangue aqui na Sul/ Odara, Odara ao povo Preto, seja obsoleto/ Talvez mais ligeiro faça tudo em segredo" ${ }^{19}$.

Assim, uma nova geração do rap brasileiro se depara com um novo público, com outras demandas sócio-culturais. Criolo, Emicida e Karol Conká, por exemplo, carregam a influência das primeiras gerações do rap nacional em relação às pautas raciais e políticas, com a liberdade mitopoética afro-brasileira que, mesmo antes presente, experimenta maior aceitação e representatividade:

Eles pensam que eu vou moscar/ Mente pequena, eu tenho dó!/ Eu não preciso de Mãe Diná/ Pra saber que é o seu pior/ Ogum adjo, ê mariô/ (Okunlakaiê)/ Ogum adjo, ê mariô/ (Okunlakaiê) ${ }^{20}$.

Então saravá Ogum, saravá Xangô, saravá/ Saravá vovó, saravá vovô, saravá/ Saravá mamãe, saravá papai, ô/ De pele ou digital, tanto faz é tambô (...)

\footnotetext{
18 Mv Bill, por exemplo, organizou um encontro de lideranças do movimento hip-hop com o presidente Lula em 2004 (TEPERMAN, 2015, p. 44). Ver mais em "Políticas Culturais no Governo Lula. Salvador: EDUFBA, 2010", de Antonio Albina Canelas Rubim.

19 Sabotage, "Cantando pro santo". Cd Rap é compromisso (São Paulo, Cosa Nostra, 2001).

20 Criolo, "Mariô", Album Nó na orelha (São Paulo, Oloko Records, 2011).
} 
/ Axé pra quem é de axé/ Pra chegar bem vilão/ Independente da sua fé/ Música é nossa religião ${ }^{21}$.

Sociedade em choque, eu vim pra incomodar/ Aqui o santo é forte, é melhor se acostumar/ Quem foi que disse que isso aqui não era pra mim/ Se equivocou/ Fui eu quem criei, vivi, escolhi, me descobri/ E agora aqui estou ${ }^{22}$.

A internet e os meios de comunicação recentes são responsáveis pela expansão dessa nova fase. Os rappers dessa geração recente dão novos rumos ao gênero musical não só em relação a mídia como ajudam o rap a se abrir para uma reflexão contemporânea sobre identidade de gênero, novas tecnologias e empreendimentos dentro da música rap. Síntese, Kivitz, Djonga, Bk, Rincon Sapiência, Baco Exu do Blues, Thiago Elninõ e Alice Guél $^{23}$ são alguns exemplos de rappers de 2012 em diante. Eles continuam se alimentando da linguagem viva de sua comunidade, de seus mitos, sonhos, relações político-raciais e de gênero, onde a experiência religiosa e os arquétipos míticos se tornam o meio pelo qual a literatura oral urbana constrói seus sentidos, narrativas e ficções.

21 Emicida, "Ubuntu Fristili", Album O glorioso retorno de quem nunca esteve aqui (São Paulo, Laboratório Fantasma, 2013).

22 Karol Conká, "É o poder", Single. (Prod. Tropkillaz, 2015).

23 "Lei dos céus fez/ Como eu bem sei/ Foram mais de três reis/ Que vieram em nosso nome/ Só faltou uma cruz de madeira/ Um cativeiro e um carcereiro/ Sequestraram o mundo/ O mundo é coveiro/Viver de joelho é demais prum Matrero" (Síntese, 2019); "Meu pai, me perdoa, mas se é de verdade essa porra/ Eu só entro descalço/ Deixei minha sandália lá fora e a mentira do hype/ Cai de joelhos, lembrei que sou pó antes de ligarem meu mic/ Eu venho em nome do sem nome" (Kivitz, 2017); "Ignorado por anjos/ Desabafei com demônios/ Separei brigas dos 2/ Eu sou Deus, sou humano (...) Eu nadei contra a maré/ Chão quente, fui a pé/ Passos descalço, eu sou Jó, sou Tomé” (Bk, 2016); "Olhei no espelho e encontrei Jesus, preto/Tipo Auto Da Compadecida" (Djonga. 2018); "Sem fuga, livre pra correr/ Um bom terreno pra plantar/ E a casa preta se ergue/ Lerê, lerê/ Não vamo mais querê/ Senzala nunca mais/ Amor ao meus Erê/ No quilombo é fuzuê/ Nosso ritual vai ter auê/ Liberdade pra vivê" (Rincon Sapiência, 2017); "Jesus, eu espanquei Jesus/ Quando vi ele chorando, gritando, falando/ Que queria ser branco, alisar o cabelo/ E botar uma lente pra ficar igual/ A imagem que vocês criaram" (Baco Exu do Blues, 2018); "E pra vocês, a lâmina de Ogum/E aos pretos, um por um/ Conforto ao colo de Oxum/E respeito comum/E que busquemos a paz de Oxalá/ Pela rota de Iemanjá/ Retorno ao que nos foi tomado/ E que Nanã nos receba de volta no solo sagrado" (Thiago Elninõ, 2016); "Pela Deusa Travesti/A Deusa dos corpos que querem Resistir/Deus é Travesti/A Deusa dor corpos que querem Existir” (Alice Guél, 2017). 


\section{O mito na obra Sobrevivendo no inferno}

Criado em 1988, Racionais MC's é formado por Mano Brown, Edi Rock, Ice Blue e Kl Jay, todos oriundos da periferia da cidade de São Paulo. Desde suas primeiras gravações (Pânico na zona sul e Fim de semana no parque), o grupo causou um enorme impacto nacional revelando uma experiência brasileira profunda e inquieta, nem sempre vista, mas que ao longo dos anos se mostrou revolucionária, contundente e controversa (TEPERMAN, 2015, p. 69). Com uma postura crítica e política, a partir dos anos 1990, Racionais MC's se torna um novo paradigma dentro e fora do rap nacional. Através da música, um novo tipo de identidade periférica estava sendo formada, onde o sujeito toma consciência do seu lugar social, dos seus direitos e da possibilidade de viver uma vida digna em meio às adversidades que a periferia apresenta. Mesmo com palavras contundentes e à primeira vista violentas, Mano Brown diz em 2003 que: "Na verdade, hoje, se eu fosse colocar um nome não seria nem Racionais, seria 'Emocionais'. Porque de racional nós não temos nada. Pra ser um cara racional tem que ser mal"24. Nas palavras do rapper Emicida: "Eu não consigo compreender exatamente quando as pessoa diz que o Racionais é só uma coisa densa, entendeu? As músicas sisuda, séria. Não mano. Pra mim, Racionais sempre foi sobre sonhos, sobre vontade de viver, sobre vida" ${ }^{25}$. Assim, abordaremos neste ponto do artigo a obra Sobrevivendo no Inferno, gravado como álbum em 1997, e em 2018 publicado pela Companhia das Letras como um livro de poesias (as letras das músicas foram transcritas em forma de texto físico).

Considerado como a "Bíblia do rap nacional"26, esse disco/livro ${ }^{27}$ marca a trajetória dos Racionais MC's em diversos aspectos, como em linguagem, estética e mensagem. A obra é considerada por Edi Rock como

24 Fala de Mano Brown no Programa Ensaio, da Tv Cultura. Disponível em: https://www. youtube.com/watch?v=Pf0YKPvz6YE\&t=1525s. Acesso em: 24 jun. 2020.

25 Depoimento do rapper Emicida no documentário Racionais Mc's: Uma história musical. (TIDAL, 2019).

26 Não só pela capa do disco ser uma alusão à estética do livro sagrado e desenvolver poeticamente um imaginário bíblico-ficcional em suas letras, "é com Sobrevivendo no inferno que os Racionais alcançaram projeção nacional, vendendo cerca de 1,5 milhão de cópias e atingindo todos os estratos sociais, de manos a playboys" (OLIVEIRA, 2018, p, 21), tornando-se uma espécie de "autoridade sagrada" dentro do rap brasileiro.

27 O termo "disco/livro" denota a complexidade da obra em questão e não um critério de valor. Sendo música, em 1997, o disco tem um significado, uma produção e uma recepção. Sendo livro (2018), além das mesmas características observadas no álbum, pode proporcionar novas reflexões teóricas, literárias e políticas. 
um "documento vivo", característica que une a obra musical à literatura oral urbana, que agora, nas em suas palavras, "virou livro, literatura, música e literatura" (Racionais 3 décadas). O consagrado compositor e cantor Caetano Veloso, comparou a obra aos clássicos da música brasileira: "Tive uma experiência com os Racionais, cujo álbum 'Sobrevivendo no inferno' é um dos maiores da história no Brasil, junto a 'Chega de saudade' e 'Pelo telefone" (VELOSO, 2005, s/n). Para Mano Brown, além do disco marcar um novo paradigma na música e na literatura, em sua visão, também é um marco social: "Que foi quando, sei lá, a classe média, a classe B descobriram que tinha favela, e tinha racismo"28.

Acauam Silvério de Oliveira abre o livro Sobrevivendo no inferno com um artigo intitulado $O$ evangelho marginal dos Racionais. Neste texto Oliveira introduz o leitor no mundo social e religioso dos Racionais MC's, discorrendo sobre a história do grupo e apontando um caminho de leitura das poesias que seguem na obra. Assim, observa-se que o pano de fundo social em que as letras são escritas estão preenchidas de um arquétipo mítico-religioso que se desdobra em todo imaginário poético, imagético e metafórico do Sobrevivendo no inferno:

Mano Brown: -Era um clima hostil. Essas músicas provocam alguma coisa diferente no ambiente, entendeu, no contexto, moro? As coisas mudam. O Racionais faz isso, o Racionais faz isso. Começa aparecer, materializar umas coisas. (...) Esse disco chamou muita 'bala perdida'. O que pra sociedade, pra sei lá, a classe artística, ou o pessoal que estuda sociedade analisou como um disco de protesto, pra nós, era cortar na própria carne, entendeu? Aquilo vinha ne nós. (...) As rima é bala perdida, compromisso mesmo. -Edi Rock: No homem na estrada já tinha começado né [a perseguição e a materialização não só das letras mas na dinâmica cotidiana da vida e dos shows do Racionais] -Mano Brown: Mas não era a mesma coisa. [Anteriormente a gente] Não mexia com Deus e o diabo, moro, essas coisas. Amém, não sei o que, pá [gesto e barulho de tiro]. Misturou tudo, e a coisa ficou, era aquilo também. Periferia era aquilo, igreja crente de um lado e bar do outro. Era aquilo, aquilo lá era o disco ${ }^{29}$.

Sobrevivendo no inferno é a síntese da periferia paulistana dos anos 1990. Entre a igreja e o bar, entre o mito e a experiência social violenta, Racionais MC's se consolida como uma "lenda", quase como "um culto

28 Depoimento de Mano Brown no documentário Racionais 3 décadas (TIDAL, 2019).

29 Trecho da entrevista do grupo Racionais Mc's realizada no programa Red Bull Station. Disponível em: https://www.youtube.com/watch?v=-D4IHZ30b2U. Acesso em: 24 jun. 2020. 


\section{Bruno de Carvalho Rocha}

Marcio Cappelli Aló Lopes

religioso" às ideias expressas nas letras e ao próprio grupo ${ }^{30}$. Oliveira diz que "é o disco mais aporético dos Racionais" (OLIVEIRA, 2015, p. 233). Entre um sentimento de incerteza e ceticismo social, ao mesmo tempo munido de uma experiência religiosa potente, onde a figura de Deus aparece como lei, como fator que confere valor à vida do sujeito periférico (KHEL, 2001, p. 1000), Sobrevivendo no inferno é uma estrutura de sentido, um "culto marginal" (OLIVEIRA, 2015, p. 324) em que as representações do mito bíblico tornam-se meio para compreender e sobreviver em uma realidade social tida como "infernal" ${ }^{31}$. Na capa do álbum (que no livro se encontra nas primeiras páginas) o Salmo 23, versículo 3, se encontra como uma das principais chaves de leitura da obra, tornando-se um caminho de interpretação do mito em toda a estrutura metafórica e narrativa do texto. Racionais MC's troca a linguagem militante dos primeiros discos e abrese a uma mitopoética capaz de comunicar efetivamente com o imaginário religioso popular do seu público.

$\mathrm{O}$ disco/livro começa com uma saudação sincrética à São Jorge/ Ogum, com a música Jorge da capadócia. A segunda faixa, Gênesis, pode ser vista como uma cosmogonia periférica, abrindo a obra como uma espécie de mitologia das origens periféricas, em que ao mesmo tempo que Deus cria o mundo, o homem inventa a maldade, o pecado e a violência. Capítulo 4, versículo 3, segunda faixa do livro, é a instauração da lei divina entre os homens. Mano Brown, como Moisés, se torna responsável em receber as leis divinas que manterão o povo vivo no "deserto". Assim, a obra segue uma organização poética rigorosa, tendo como base estrutural o mito judaicocristão, um início, meio e fim, que culmina na instauração de uma palavra divina (OLIVEIRA, 2015, p. 226) em direção à Fórmula mágica da pa žn , um tipo de redenção onde a periferia se apropria de uma nova realidade: "Você foi feito pra correr nos campos, andar de cavalo, andando entre crianças,

30 Depoimento de Mano Brown no documentário Racionais Mc's: Uma história musical (TIDAL, 2019).

31 "Nesse caso, portanto, os sentidos semânticos que servem para maquiar a realidade são descartados, e a imagem se volta contra o próprio sistema que a transformou em ideologia. Sobreviver, nesse caso, é necessariamente contra hegemônico. (...) O inferno nesse caso não pressupõe uma comunidade de cristãos e nem remete a um lugar específico repleto de demônios, ainda que seu impacto semântico se deva a forte presença da cultura cristã (...). Inferno é o nome do campo de extermínio a céu aberto que se tornaram as periferias brasileiras (OLIVEIRA, 2015, p. 269).

32 Racionais Mc's, "Fórmula mágica da paz", Lp Sobrevivendo no inferno. (São Paulo, Cosa Nostra Fonográfica, 1997). 
cachorros, velhos, entendeu rapaz? Flores, natureza, rios, água limpa pra beber, rapaz. Essa foi a vida que Deus preparou pra você" 33 .

O álbum Sobrevivendo no inferno oferece um caminho próprio de análise do mito a partir do imaginário religioso popular brasileiro. Através da obra, é possível constatar que o grupo Racionais oferece uma leitura de mundo através do mito e metáforas que fazem parte da religiosidade cristã no Brasil. O filósofo e cientista da religião Rui Josgrilberg diz que as metáforas revelam uma estratégia de significado polissêmico do mito, implicando um trabalho hermenêutico (JOSGRILBERG, 2014, p. 67). Assim, é preciso interpretar o mito para compreender a produção metafórica dos seus sentidos tanto nos textos do rap como na tradição das culturas:

O mito, como a metáfora, une duas ou mais esferas de significação estabelecendo uma relação produtiva entre elas. Essa relação ordena um mundo ou uma parte do mundo. O mito ordena por uma palavra exemplar e originária o aparecimento das coisas e das ações humanas. Esse caráter originário fornece intuições sobre nossas archês (JOSGRILBERG, 2014, p. 67).

Sobrevivendo no inferno, como uma obra assentada no arquétipo míticoliterário, desenrola uma cadeia de imagens com sequências temporais, personagens, acontecimentos, ação, experiência religiosa, segundo uma lógica interna que lhe confere precisamente a dimensão de uma história, uma intriga social, uma dramatização (VAZ, 2007, p. 55). Este livro/disco marca a produção cultural periférica brasileira como um testemunho teo-político da realidade nacional. Compõe também o imaginário religioso popular e estabelece o mito como arquétipo ou recurso literário sempre presente na experiência social da literatura oral urbana.

\section{Cosmogonia periférica e a leitura metafórica do mito}

A literatura é a possibilidade de reconstrução do mundo e da realidade. Cada agente do rap nacional utiliza-se da literatura oral urbana à sua maneira, tendo muitas vezes o mito - como foi visto no primeiro ponto do artigo como arquétipo literário de experiências sociais e religiosas contemporâneas. O rap pode ser um espaço literário de construção do mito: “Deus mostrou

33 Fala de Mano Brown no final da música "Fórmula mágica da paz", no show 1000 trutas e 1000 tretas, em 2006. Disponível em: https://www.youtube.com/watch?v=9nUHk06-bX4. Acesso em: 22 jun. 2020. 


\section{Bruno de Carvalho Rocha}

Marcio Cappelli Aló Lopes

o rap e fez do corpo a ferramenta" ${ }^{34}$. Ele proporciona um caminho de expressão da subjetividade do ser e a construção do seu sentido social, mesmo que através de representações não tão precisas ou ortodoxas. O rapper Neto, integrante do grupo Síntese, admite os limites de sua mensagem: "Fala é um atrofiamento da nossa comunicação" "35. Mesmo a linguagem sendo um conjunto de símbolos e metáforas limitadas, que pelo vasto campo semântico das palavras nem sempre condiz com a intenção do locutor, o mito acaba sendo a articulação entre o mistério da existência e a objetividade imanente. A arte, seja qual for a linguagem, utiliza-se do mito para ler e reler o real que se mostra, trazendo uma compreensão original do princípio da vida a partir de imagens e metáforas. Assim, o rap apresenta-se enquanto um caminho hermenêutico na busca da realidade última que, na experiência da cultura popular brasileira, vem acompanhada de uma imaginário mítico-religioso próprio. Nas palavras do rapper Criolo: "Rap, que energia é essa?!, um dom, um karma, uma dívida, uma prece" ${ }^{\prime 6}$.

\section{1 "Gênesis"}

Deus fez o mar, as árvore, as criança, o amor

O homem me deu a favela, o crack, a trairagem, as arma, as bebida, as puta Eu? Eu tenho uma Bíblia velha, uma pistola automática e um sentimento de revolta Eu tô tentando sobreviver no inferno "Gênesis", Mano Brown

Pensar o início da humanidade nos leva à diversos campos do saber. A filosofia, a ciência ou a biologia, por exemplo, já discutiram de maneira exaustiva sobre o tema. Muitas vezes, em conflitos e tensões com instituições religiosas. Até mesmo na contemporaneidade, esse debate ainda se faz pertinente no âmbito do ensino básico, por exemplo, transformandose em um tipo de disputa ideológica rasa entre conservadores religiosos (criacionistas) e progressistas ateus (evolucionistas). A teologia se debruça também sobre o tema. De maneira apologética, ela travou a maioria das vezes um debate fundamentalista, pseudo-científico/filosófico e até mesmo

\footnotetext{
34 Criolo, "Roba a cena", Cd Ainda há tempo (São Paulo, Sky Blue Music, 2006).

35 Síntese, "Carta aos caçadores de leões". Disponível em: https://www.youtube.com/ watch?v=c3ko-8S6UtU. Acesso em: 24 jun. 2020.

36 Criolo, “Ainda há tempo", Cd Ainda há tempo (São Paulo, Sky Blue Music, 2006).
} 
historicista do seu ponto de vista. Ela muitas vezes acabou perdendo o horizonte do diálogo e da abertura para a reflexão sobre a potência que uma leitura aberta do mito pode trazer à fé e à teologia. Fato é que, o mito cosmogônico, ou, pensar histórias das origens, pode ser enriquecedor para todos os campos do saber e, para a reflexão deste artigo, uma chave muito importante para entender a obra Sobrevivendo no inferno.

Os estudos mais recentes apontam que o mito bíblico da criação é um compilado de mitos de origens das diversas culturas que cercavam o povo hebreu (VAZ, 2007, pp. 46-47). A cosmogonia é um gênero textual que conta a origem da humanidade a partir da revelação divina em uma determinada cultura. O mito cosmogônico tem a função de preservar a memória das tradições humanas e revelar a experiência social e subjetiva de um grupo. Ele é a uma narrativa, um instrumento literário que cria identidade e localiza o ser no tempo e seu significado. Os mitos de origem ordenam o caos, o vazio, aquilo que era disforme, mas que pelo poder das palavras, organizam, classificam e nomeiam fragmentações e fissuras profundas de sentido das nossas consciências (JOSGRILBERG, 2014, pp. 74-75). Assim, é possível compreender que a escolha de Mano Brown por esse recurso literário, no começo da obra em questão, ultrapassa a discussão religiosa e a simples afirmação de que o cristianismo seria um elemento normativo da escrita e da experiência religiosa do grupo.

Acauam Oliveira sublinha que o álbum Sobrevivendo no inferno teria a presença de incontáveis sugestões teológicas em seu desenvolvimento, e que sua estrutura narrativa poderia ser comparada a um "culto" em que se explora contradições entre os modelos éticos da religião com o contexto social violento e desigual (OLIVEIRA, 2018, p. 33). Oliveira sugere, então, que Gênesis seria a "leitura do evangelho marginal", ou seja, um caminho de leitura introdutória de uma obra que se desdobra em histórias contraditórias, busca de identidade e experiências mítico-religiosas plurais. Mano Brown, como é próprio dos grandes mitólogos, cria um novo mito cosmogônico a partir de sua experiência estético-social, subjetiva e religiosa, mas agora, na visão da periferia.

A figura de Deus se manifesta como quem projeta uma instância de sentido, autoridade e organização harmônica inicial. Ele compreende que o relato bíblico, tão presente no imaginário popular brasileiro, tem o seu lugar na ficcionalidade literária, e estabelece alguns elementos que provam em sua história a presença de uma realidade próxima do que seria o "paraíso", seu 


\section{Bruno de Carvalho Rocha}

Marcio Cappelli Aló Lopes

jardim do Éden: "Deus fez o mar, as árvore, as criança, o amor". Nota-se que para Brown, a criança é anterior à criação do homem adulto e que o amor encerra o sentimento perfeito da criação de Deus. Logo em seguida, ele destaca o que a figura desse homem, que veio depois da criança e do amor, lhe deu: "O homem me deu a favela, o crack, a trairagem, as arma, as bebida, as puta". Neste trecho é listado sua visão sobre a realidade em que vive. Seu contexto enquanto homem negro, pobre e desassistido pelo Estado brasileiro é o oposto do que Deus havia projetado anteriormente. Como uma espécie de "pecado inicial" ou de "queda" do sentido de humanidade, a figura desse homem perverso é a encarnação da desobediência à Deus, e como consequência, experimenta a quebra da harmonia da criação, o aniquilamento do arquétipo do estado infantil (inocente) e o afastamento do amor. O resultado é a criação da favela (lugar longe do mar e das árvores), o crack e a bebida (distância do arquétipo da criança) e a trairagem, as armas e as putas (elementos contrários ao amor).

Sendo o mito uma linguagem simbólica em forma de narrativa (VAZ, 2007, p. 71), Gênesis poderia ser interpretado como metáfora de uma representação social da literatura oral urbana, em que a cosmogonia bíblica é relida juntamente ao contexto periférico paulistano. A crise do crack que chega na periferia do brasil nos anos 1990, o alcoolismo, a violência da criminalidade e a prostituição como fonte de sustento, denunciam uma condição social de extrema vulnerabilidade. Nessa situação, parece não existir um jeito ortodoxo de experienciar a religião ou a sociedade. Mano Brown traz uma resposta em sua cosmogonia periférica: "Eu? Eu tenho uma Bíblia velha, uma pistola automática e um sentimento de revolta/ Eu tô tentando sobreviver no inferno". A Bíblia ao lado de uma pistola parece não ser uma contradição. O sentimento de revolta é inerente à sobrevivência no inferno. Walter Garcia afirma que "ao sustentar uma ideia de Bem que não se concretiza na realidade da periferia urbana [sobreviver no inferno]", o Deus de Brown, "tão antigo quanto humilde (Bíblia velha) se alia ao armamento moderno (pistola automática) e ao inconformismo do sujeito" (GARCIA, 2013, p. 96). A presença de Deus no mito periférico, simbolicamente representada na "Bỉblia velha", ainda se coloca enquanto lugar de sustentação de uma harmonia social original, ao mesmo tempo em que não se encontra passivo dentro de uma realidade em que é preciso se prostituir ou ter a posse de uma pistola para sobreviver.

Gênesis em Racionais MC's, é uma proposta de contar as origens de um mundo pouco falado ou representado. É um mito cosmogônico atravessado 
por tudo aquilo que forma o sujeito periférico: sua classe, raça e gênero. O mito da criação bíblica torna-se o modelo imagético da literatura oral urbana, e seu desenvolvimento se torna visível no decorrer da poética da obra Sobrevivendo no inferno.

\section{2 "Capítulo 4, versículo 3"}

Northrop Frye, em seu livro "Código dos códigos: a Bíblia e a literatura”, observa que a Bíblia é um livro essencial na formação e para a compreensão da literatura ocidental. Assim como os clássicos de Homero, Fronçois Rebelais ou Luiz Vaz de Camões, sem o entendimento do universo simbólico e mitológico entorno do texto bíblico e sua importância enquanto influência do imaginário literário brasileiro, por exemplo, seria uma enorme perda tanto para a crítica literária quanto às diversas outras áreas do conhecimento (FRYE, 2004, p.10). Olhar para a Bíblia enquanto uma obra literária se torna imprescindível para um trabalho hermenêutico relevante e atual, afastando-se da habitual aversão da comunidade acadêmica à religião. Além, é claro, de não estar submetido a tutela das instituições confessionais e nem estar preocupado em fazer do texto um objeto normativo ou teológico (LIMA, 2015, p. 156).

Enquanto parte da literatura oral urbana nacional, o grupo Racionais MC's está sob a influência histórica do cristianismo, mas não só. Figuras e elementos das religiões afro-brasileiras são encontrados no decorrer de suas obras, mesmo no disco Sobrevivendo no inferno ${ }^{37}$. O pensamento mitológico é reescrito e recontado a partir do contexto e das experiências de determinada comunidade. O cristianismo popular periférico, longe dos grandes centros teológico, se recria na múltipla pertença, no resgate ancestral e da tradição oral. Assim, a presença católica, pentecostal ou mesmo do candomblé, fazem parte do imaginário religioso na periferia (D’ANDREA, 2014, pp. 40 e 111).

A começar com o título da música, é interessante observar como Mano Brown tem em mente diversas imagens, referências e modos de uso da Bíblia.

37 É possível, observar elementos das religiões de matriz africana, por exemplo, nas músicas "Jorge da capadócia" e "Formula magica da paz", no álbum Sobrevivendo no inferno, ou na música "Homem na estrada", do álbum Raio- $X$ do Brasil. Ou ver o trecho em que Mano Brown comenta uma fase difícil do grupo Racionais Mc's em que foram em uma "encruzilhada", "acender umas vela", pedir "proteção" para os "caminho abrir", indicando uma proximidade com religiões de matriz africana. Disponivel em: https://www.youtube.com/watch?v=mEIvL6VZ4bM. Acesso em: 24 jun. 2020. 


\section{Bruno de Carvalho Rocha}

Marcio Cappelli Aló Lopes

Este livro não é algo distante do imaginário poético e subjetivo do grupo. Não só em seu conteúdo, a Bíblia carrega um significado social intrínseco na cultura brasileira, e consequentemente, no rap. Suas histórias, mitos e sagas animam a produção artística da periferia. Ela se torna repertório para a comunicação dentro do contexto periférico, onde a religião é tão presente. A Bíblia é um lugar onde os rappers tirarm metáforas para o estabelecimento de uma "teologia de sobrevivência" (como observado em Gênesis). Nesse jogo de sentidos e significados, Racionais MC's se torna um símbolo de autoridade e suas letras, consequentemente, um tipo de escritura sagrada que transforma aquele que faz contato com ela. Ao colocar o nome da música como se esta fizesse parte do livro sagrado, ou até mesmo como se ela testemunhasse um outro evangelho, um "evangelho marginal" (Racionais, capitulo 4, versiculo 3), Brown atribui um sentido religioso às próprias ideias da sua poesia e a estabelece como doutrina sagrada, assim como a Bíblia:

Minha palavra alivia sua dor, ilumina minha alma

Louvado seja o meu Senhor

Que não deixa o mano aqui desandar

E nem senta o dedo em nenhum pilantra

Mais que nenhum filha da puta ignore a minha lei

Racionais, capítulo 4 versículo $3^{38}$

Observando o funcionamento da cosmogonia periférica em Gênesis, pode-se compreender que o objetivo da narrativa do grupo Racionais é mostrar e organizar as representações da realidade, denunciá-la, e estabelecer estratégias de sobrevivência dentro do "inferno" social. Em Sobrevivendo no Inferno, o grupo de rap se comporta como "pastor marginal", que procura estabelecer juntamente com o "Senhor" alguns parâmetros e leis; para que "nenhum mano desande" e nem tenha que "sentar o dedo em nenhum filha da puta", concretizando o motivo da pistola e a Bíblia andarem sempre juntos dentro da narrativa. A "lei da favela" 39 da qual Racionais Mc's tenta ser portavoz se assemelha com a missão que Moisés, um dos grandes personagens da história do povo hebreu, teve no deserto. Com muito temor, mas encorajado pela revelação de Yahweh, Moisés é protagonista da libertação do povo de

\footnotetext{
38 Racionais Mc's, “Capítulo 4, versículo 3", Lp Sobrevivendo no inferno. (São Paulo, Cosa Nostra Fonográfica, 1997).

39 Racionais Mc's, "Formula magica da paz", Lp Sobrevivendo no inferno. (São Paulo, Cosa Nostra Fonográfica, 1997).
} 
Israel. Ele foi o mensageiro, o profeta de Deus tanto para o povo como diante do rei opressor do Egito. Depois da libertação dos hebreus, a história nos conta que Deus leva Moisés até um monte e lhe entrega as tábuas da lei (os 10 mandamento) que ajudariam na condução e na manutenção futura da vida daquele povo. Mano Brown, assim como Moisés, também é portador de uma lei, mas em forma de rap. Seria através dos Racionais MC's que a periferia enfrentaria o seu "deserto" com palavras de refrigério, ou como o versículo da capa do álbum diz, sendo guiado "pelas veredas da justiça". Mano Brown enquanto um "bandido do céu", atenta o sujeito periférico à ouvir suas palavras porque essas são palavras de salvação contra a violência polícial $^{40}$, o racismo ${ }^{41}$ e a miséria social ${ }^{42}$ :

Violentamente pacífico, verídico

Vim pra sabotar seu raciocínio

E pra abalar seu sistema nervoso e sanguíneo

Pra mim ainda eh pouco, dá cachorro louco

Número um dia terrorista da periferia

Uni-duni-tê o que eu tenho pra você

Um rap venenoso ou uma rajada de PT

E a profecia se fez como previsto

(1997) depois de Cristo a fúria negra ressuscita outra vez

Racionais, capítulo quatro versículo três ${ }^{43}$

40 Trecho da música "Capítulo 4, versículo 3": "60\% dos jovens de periferia/ Sem antecedentes criminais/ Já sofreram violência policial/ A cada quatro pessoas mortas pela polícia, três são negras/ Nas universidades brasileiras/ Apenas 2\% dos alunos são negros/A cada quatro horas um jovem negro morre violentamente em São Paulo/ Aqui quem fala é Primo Preto mais um sobrevivente".

41 Trecho da música "Capítulo 4, versículo 3": "Ser um preto tipo A custa caro/ É foda, foda é assistir a propaganda e ver/ Não dá pra ter aquilo pra você/ Playboy forgado de brinco, um trouxa/ Roubado dentro do carro na Avenida Rebouças/ Correntinha das moça, as madame de bolsa, dinheiro/ Não tive pai, não sou herdeiro".

42 Trecho da música "Capítulo 4, versículo 3": "Quatro minutos se passaram e ninguém viu/ O monstro que nasceu em algum lugar do Brasil/ Talvez o mano que trampa debaixo do carro sujo de óleo/ Que enquadra o carro forte na febre com o sangue nos olhos/ O mano que entrega envelope o dia inteiro no sol/ Ou o que vende chocolate de farol em farol/ Talvez o cara que defende o pobre no tribunal/ Ou o que procura vida nova na condicional".

43 Racionais Mc's, “Capítulo 4, versículo 3”, Lp Sobrevivendo no inferno. (São Paulo, Cosa Nostra Fonográfica, 1997). 


\section{Bruno de Carvalho Rocha}

Marcio Cappelli Aló Lopes

É importante notar também no final do verso acima, que a construção do mito em toda a obra pode ser lida não só a partir das tensões de classe social, mas pela metáfora construída em torno da raça. Não cabe nesta reflexão a discussão conceitual e problemática destes termos, mas é possível ver que a experiência dos quatro integrantes do grupo de rap, enquanto homens negros, perpassa não só a militância política ${ }^{44}$ mas sua experiência religiosa ancestral vinda da África e sincretizada na diáspora brasileira. Primeiro, Mano Brown compara a força das palavras do seu rap como uma rajada "venenosa" de tiros. Depois, suas palavras são equiparadas à profecia bíblica neotestamentária, em que Jesus promete que iria voltar à terra para redimir os injustiçados e levar ao Reino dos Céus aqueles que seguiram os seus preceitos e sua lei. Racionais MC's enquanto livro e palavra sagrada, feito uma profecia negra furiosa, se coloca enquanto metáfora do próprio Cristo. Porém, dessa vez, um messias nascido não na periferia de Jerusalém, mas na periferia da cidade de São Paulo, em 1997 (ano de lançamento do álbum).

Para Mano Brown, só há a possibilidade de uma criação narrativa mítica se as figuras, imagens e metáforas couberem dentro do seu contexto social e racial. Sua cosmogonia é periférica e seu Cristo é negro, furioso; está pronto para um revide social e espiritual, a fim de vingar todas as injustiças sofridas dentro das comunidades marginalizadas do Brasil. $\mathrm{Na}$ última faixa do disco intitulada Salve, mano Brown reafirma o lugar do mito e o reveste de uma linguagem metafórica, influenciando o imaginário literário de toda a obra. Essa presença não é apenas uma estrutura ficcional, mas como um testemunho, o mito encarna identidade, memória e a experiência social da periferia: "Eu acredito na palavra de um homem de pele escura, de cabelo crespo, que andava entre mendigos e leprosos, pregando a igualdade. Um homem chamado Jesus. Só ele sabe a minha hora. Aí ladrão, tô saindo fora. Paz".

\section{Considerações finais}

Sobrevivendo no inferno foi um marco na cultura brasileira e na história da literatura oral urbana. Sua narrativa é complexa e possibilita diversas abordagens, inclusive dentro do campo das Ciências da religião. O fenômeno religioso pode ser percebido na obra através da construção narrativa das experiências sociais e por meio do arquétipo literário proporcionado pelo pensamento mítico, que conta e recria uma memória social ancestral e religiosa própria da periferia brasileira.

44 Ver as músicas: "Negro limitado", "Juri Racional" e "Voz ativa". 
Racionais MC's enquanto parte de um movimento cultural híbrido, se soma à uma tradição do rap brasileiro que usa das experiências míticoreligiosas para construção de sentido, organização do caos de uma comunidade desassistida pelo Estado e estruturação de sua narrativa. Sobrevivendo no inferno parte do imaginário religioso popular e coletivo de uma comunidade e se instaura como um potente discurso literário, político e religioso. O mito é transposto para a vida cotidiana por meio de metáforas que ajudam a mediar narrativas e imagens do real, não sendo possível desvincular nenhuma das características da comunidade em questão. Assim, é preciso levar em consideração as tensões de classe, gênero e raça que permeiam a obra e a carreira do grupo. Mano Brown, Ice Blue, Edi Rock e Kl Jay tornam-se verdadeiros mitógrafos, preocupados em ressignificar, atribuir valor à vida $\mathrm{e}$ lutar pela preservação dos valores e pela sobrevivência dos sujeitos periféricos.

\section{Referências}

BÉTHUNE, Christian. Le Rap. Une esthétique hors la loi. Paris: Autrement, 2003.

Consciência Black Vol. I. São Paulo, Zimbabwe Records, 1989. Disponivel em: https:// www.youtube.com/watch?v=CXN21X2YrWk. Acesso em: 24 jun. 2020.

Criolo. 2011. 1 vídeo (48 min e 22s). Publicado no canal Programa Ensaio. Disponível em: https://www.youtube.com/watch?v=Eq8V17dkAwg\&t=2393s. Acesso em: 24 jun. 2020.

D’ANDREA, Tiarajú Pablo. A formação dos sujeitos periféricos: Cultura e Política na periferia de São Paulo. São Paulo, 2013. 309 p. Tese (Doutorado em Sociologia) Universidade de São Paulo, São Paulo, 2013. [Orientada por $\operatorname{Prof}^{a}$ Dr $^{a}$ Vera da Silva Telles].

ELIADE, Mircea. O mito e a realidade. São Paulo: Perspectiva, 1978.

FERRÉZ. Capão Pecado. São Paulo: Labortexto Editorial, 2000.

FRYE, Northrop. Anatomia da crítica. São Paulo: Editora Cultrix, 1957.

FRYE, Northrop. Fábulas de identidade. Trad. Sandra Vasconcelos. São Paulo: Nova Alexandria, 2000.

FRYE, Northrop. O código dos códigos: a Bíblia e a literatura. Trad. Flávio Aguiar - São Paulo: Boitempo, 2004.

GARCIA, Walter. Elementos para a crítica da estética do Racionais Mc's 1990-2006. Idéias, Campinas, nova série, n.7, p.81-110, $2^{\circ}$ semestre, 2013.

GILROY, Paul. O atlântico negro: modernidade e dupla consciência. Trad. Cid Knipel Moreira. São Paulo: Ed. 34; Rio de Janeiro: Universidade Cândico Mendes, Centro de Estudos Afro-Asiáticos, 2001.

Hip-hop cultura de rua. São Paulo, Paralelo, 1988. Disponível em: https://www.youtube. $\mathrm{com} /$ watch?v=ISpyWlr4pU0\&list=PLaHa36svZa_3n8WpyRuLhkUolpK5UQ0om. Acesso em: 24 jun. 2020. 
176 Bruno de Carvalho Rocha

Marcio Cappelli Aló Lopes

JOSGRILBERG, Rui. "O mito, uma interpretação metafórica”. In: Estudos em antropologia e linguagem. (Orgs.) JOSGRILBERG, Rui; LAUAND, Jean. São Paulo: Factash Editora, 2014.

KEHL, Maria Rita. "Radicais, Raciais, Racionais: a grande fratria do rap na periferia de São Paulo”. São Paulo em Perspectiva, São Paulo, v. 7, n. 3, 95-106, 1999.

LEITE, Guto. "Dos tropicais aos Racionais: premeditando o brete". In: Poesia contemporânea: crítica e transdisciplinaridade. Rio de Janeiro: ABRALIC: Associação Brasileira de Literatura Comparada, 2018.

LIMA, Anderson de Oliveira. "A Bíblia como literatura - a Bíblia como ficção". In: Estudos de Religião, v. 29, n.1, p.155-168, jan-jun, 2015.

Mano Brown. 2003. 1 vídeo (49 min e 12s). Publicado no canal Programa Ensaio. Disponível em: https://www.youtube.com/watch?v=Pf0YKPvz6YE\&t=1525s. Acesso em: 24 jun. 2020.

MIElietinski, E. M. A poética do mito. Trad. Paulo Bezerra. Rio de Janeiro: ForenseUniversitária, 1987.

MONFARDINI, Adriana. O mito e a literatura. Terra roxa e outras terras - Revista de estudos literários. v. 5, p. 50-61, 2005.

OLIVEIRA, Acauam Silvério. “O Evangelho marginal dos Racionais Mc's”. In: Racionais Mc's: Sobrevivendo no Inferno. São Paulo: Companhia das Letras, 2018.

OLIVEIRA, Acauam Silvério. O fim da canção? Racionais Mc's como efeito colateral do sistema cancional brasileiro. São Paulo, 2015. 412 p. Tese (Doutorado em Letras) Universidade de São Paulo (USP), São Paulo, 2015. [Orientado por Prof. Dr. José Miguel Soares Wisnik].

Racionais Mc's: Uma história musical. São Paulo: TIDAL, 2019. (10min.).

Racionais 3 décadas. São Paulo: TIDAL, 2019. (18min.)

RIBEIRO, Maria Goretti. Da literatura aos mitos: a mitopoética na literatura de Lya Luft. Interdisciplinar, v. 7, $\mathrm{n}^{\circ}$ 7, p.59-79, jul.-dez., 2008.

ROCHA, João Cezar de Castro. A guerra de relatos no Brasil contemporâneo. Ou: A "Dialética da marginalidade". Letras, Santa Maria/RS, n. 32, p.25-70, 2007.

SALGADO, Marcus Rogério. Entre ritmo e poesia: rap e literatura oral urbana. Scripta (Belo Horizonte), v.19, n.37, p.151-163, $2^{\circ}$ sem. 2015.

SILVA, J. C. G. Rap e educação. Rap é educação. São Paulo: Selo Negro (Summus), 1999.

SOUZA, Ana Lúcia Silva. Letramentos de Reexistência. Poesia, Grafit e, Música, Dança: Hip-Hop. São Paulo, Parábola, 2011.

TEPERMAN, Ricardo. Se Liga no Som: As transformações do rap no Brasil. São Paulo: Claro Enigma, 2015.

VAZ, Armindo dos Santos. No princípio da Bíblia está o mito: a espiritualidade dos mitos de criação. Didaskalia XXXVII, v. 1, p. 45-73, 2007.

Submetido em: 5-10-2020

Aceito em: 26-11-2020 